\title{
RADICAL THACHRR
}

A SOCIALIST, FEMINIST, AND ANTI-RACIST JOURNAL ON THE THEORY AND PRACTICE OF TEACHING

\section{Beautiful Dark Twisted Pedagogy: \\ Kanye West and the Lessons of Participatory Culture}

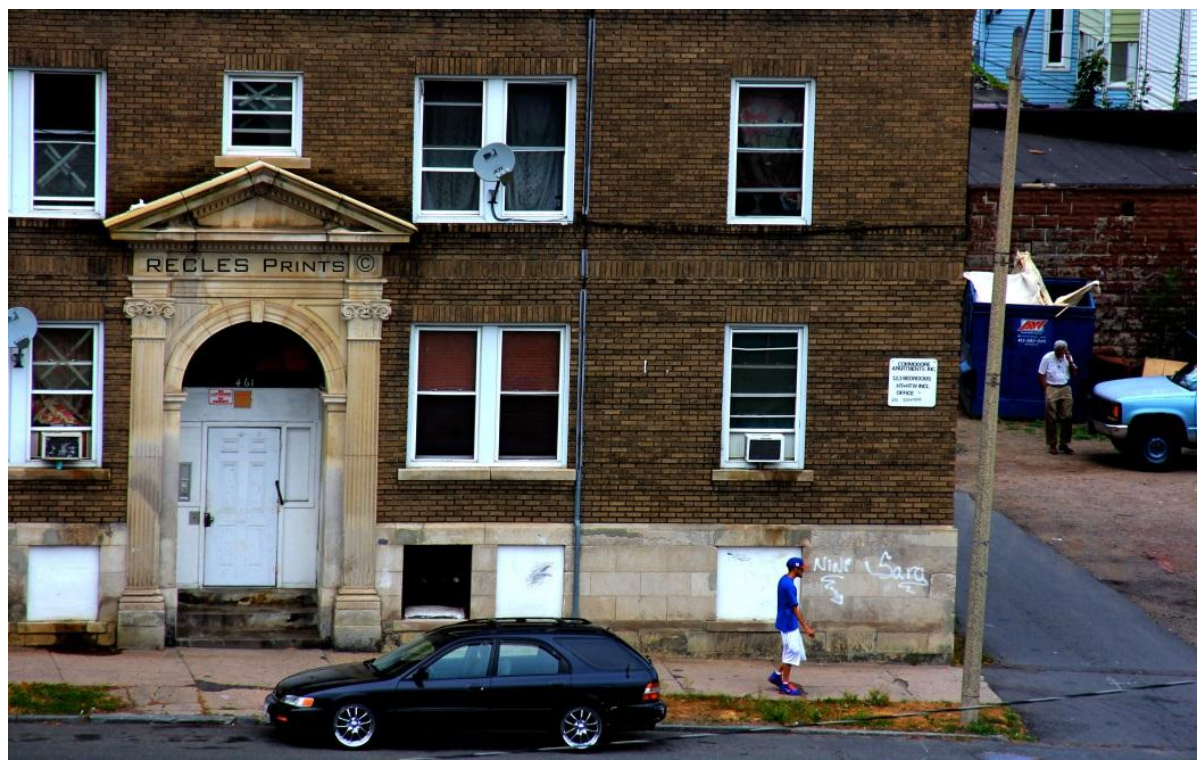

"HUGGIN' THE BLOCK" PHOTO BY CARLOS MCBRIDE 
0 ver the fall of 2010, rapper Kanye West reimagined the way music was distributed. He did this by engaging in an online conversation with millions. For the greater part of that year, Kanye West was firmly present on the cultural radar. This was deliberate and done in a way that made his presence, his performances, and his music an ongoing conversation with his fans, with his past, and with a larger network of engaged online participants. Through demonstrating the affordances of participatory culture, West presents a framework for engagement and communication that critical educators can leverage even within the increasingly restrictive space of public education. Though the capitalist practices that led to his album spending more than six months on the Billboard 200 may not seem like the obvious place to search for liberatory educational pedagogy, I argue that the strategies developed and tested by West offer an important framework for guiding critical consciousness and fomenting action within our classrooms.

As a Hip Hop fan and former music journalist, I often infused my classroom with beats and rhymes. Whether it was the first Lupe Fiasco album encouraging my students to consider the blend between Hip Hop and skateboarder social groups on my campus or formally utilizing classics like Grandmaster Flash's "The Message" and Dead Prez's "Police State" as starting points for literary and critical analysis, Hip Hop played a formative part in my teaching practice. For the eight years that I spent teaching English and ELL courses at a public school in South Central Los Angeles, my classroom breathed Hip Hop as well as music across genres to speak to the diverse youth population I worked with. Comprised of approximately $80 \%$ of my students identifying as Latino and $19 \%$ as Black and a dropout rate that rocketed above $60 \%$, my school was characterized in the media by stereotypes of a failing school while my students exuded the passion to learn that showed me an optimism in transforming schools. Throughout this teaching time, I can see now how Kanye West's music acted as a through line in my classroom. On a year-round schedule, my first year teaching allowed me to bring in West's infamous 2005 declaration that "George Bush doesn't care about Black people" during a Hurricane Katrina relief telethon. Meanwhile West's singles filtered into my classroom as music played by students or analyzed for various writing assignments. At the time that West revolutionized media distribution and opportunities for pedagogical growth in 2010, I was working with ninth grade students and exploring how mobile devices like iPods could help connect urban youth with civically engaging movements beyond the classroom (Garcia, 2012a).

Just in time to be heralded critically by music publications ranging from $X X L$ to Rolling Stone, Kanye West's fifth solo album My Beautiful Dark Twisted Fantasy was released in the United States on November 22, 2010. However, even by the time the album leaked through file sharing networks and torrents online, weeks before the official release date, its music was anything but surprising. Via his own music label, G.O.O.D. (Getting Out Our Dreams), West leaked many of the tracks from his album as free downloads during the fall. A matter of a few clicks from his official website yielded more than snippets from the album. Releasing one song each week on "G.O.O.D.
Fridays," responding to challenges and criticism from fans via Twitter, West sustained interest and anticipation throughout the world. In addition to a slew of tracks from the album including the lead single "Power," West released numerous tracks that were subsequently never officially included in the final album. Speculation of what would make the cut drove buzz around My Beautiful Dark Twisted Fantasy rather than speculation about what kind of sound the album would take. By the end of 2010, fifteen different tracks were given away by West, including two of the lead singles from his album: a remix of "Power" and the cameofilled "Monster." Through use of simple and public media tools like Twitter, West moved popular hip-hop models of marketing beyond traditional mixtape culture and illustrated how participatory culture can help foment profit as well as awareness and social organization.

\section{Moving Beyond the Mixtape}

As far as Hip Hop is concerned, the role of mixtapes is one that dates back to the early days of Hip Hop in the late '70s (Westhoff, 2011). Splicing together popular rap verses with unreleased Hip Hop beats, mixtapes were underground commodities traded and sold by the aficionados within an exclusive subculture. Though it has been years since mixtapes were widely distributed as actual cassettes, the concept is still the same; otherwise unreleased or un-cleared samples are released noncommercially. Like electronic music's prevalent use of "white label", unofficial releases (Reynolds, 1999), to help build interest in a track, Hip Hop has incorporated mixtapes as more than underground productions by individuals and part of a larger marketing and distribution ecology. Transitioning from tapes to CDs and now to direct Internet downloads, mixtapes are used by mainstream rappers to sustain interest between album releases. Lil' Wayne, for example, has benefited from a plethora of mixtape releases that have helped garner radio play and online reviews long before his albums are available for media consumers (Westhoff, 2011). No longer are mixtapes simply an extension of the listening experience for rap fans. Instead, they act as previews and major marketing ploys for Hip Hop artists. Additionally, because they are steeped in the history of Hip Hop, they may signal an artist's credibility for some rap fans. However, where the mixtape largely succeeded in previewing a forthcoming album and playing with the expected commercial limitations of what could be released, Kanye West takes the model and deconstructs it.

\section{The recognition that today's media consumer is also a media producer means that sustaining interest means responsiveness.}

Instead of the mishmash of 40-70 minutes of free music usually released on a mixtape, West slowly strings along track after track over months at a time, responding and changing his music as responses are blogged and status-updated. In one notable example, teen-idol Justin Bieber, upon hearing that Kanye liked his song "Runaway Love" tweeted, "@kanyewest it's not a so what moment for me. I'm 16 and a fan. I'm kinda hyped $u$ are listening to 
my stuff. Thank u. Nice sunday morning" (Vilensky, 2010). Shortly afterwards, West responded to fomenting interest from online fans and released his remix of "Runaway Love" featuring both West and Wu Tang rapper Raekwon.

In terms of his album, My Beautiful Dark Twisted Fantasy also built upon mixtape culture by reflecting the practice within the production of his album. The silly mashup of unexpected artists that is typically reserved for mixtapes became a centerpiece for the album: softcrooning indie musician Justin Vernon of the band Bon Iver is featured prominently in the album's penultimate song, "Lost in the World;" Vernon's lilting voice is paired earnestly with Hip Hop verses. No longer a mixtape novelty, West builds upon accepted underground Hip Hop practices and subverts what is expected within commercial Hip Hop.

\section{Amplification and the Participatory Culture of G.O.O.D. Fridays}

Though the mixtape formula was popular in subverting official release dates, West moved from the singular verses and cobbled together mixes of unreleased music to a model that placed agency and music decisions in the hands of his fans. In short, Kanye West released music in ways that utilized the connected culture of social media to invigorate enthusiasm and to build camaraderie with a continually building fan base. Henry Jenkins et al. (2009) describe the ways media as "participatory culture" shift "the focus of literacy from individual expression to community involvement."

Further, Jenkins et al. write, "Participatory culture is emerging as the culture absorbs and responds to the explosion of new media technologies that make it possible for average consumers to archive, annotate, appropriate, and recirculate media content in powerful new ways." West's G.O.O.D. Friday releases, in responding to and encouraging dialogue with his fans, indicate a mass media application of participatory culture for profit. However, the general tenets of participatory culture typically wrest control of media distribution from traditional mass media outlets in ways that empower teens fluent with the tools on their laptops and smartphones.

The recognition that today's media consumer is also a media producer means that sustaining interest means responsiveness. It wasn't enough, for instance, for West to thank Bieber for the Twitter shout out. The voice (and the thousands that followed echoing wishes to see a collaboration between the two musical stars) encouraged participation, remix and playfulness. YouTube is rife with tributes and parodies of West's songs. From a version of his song "Monster" that pays tribute to the food at Taco Bell (http://www.youtube.com/watch?v=CnUKmk5Lz50) to one that is sung by Harry Potter's nemesis Voldermort (http://www.youtube.com/watch?v=hA7leadDk9g), the digital tools online allow for new forms of participation and engagement. In my own research on how young people may be able to challenge existing power structures and dominant narratives via social tools, I have described the potential of participatory culture as an "amplifying" process (Garcia, 2012b). In the public, persistent spaces of Twitter, YouTube, and Facebook, for instance, comments youth make can be seen by anybody. However, within the educational world, the participatory culture of out-of-school time is frequently stifled by school and district policies that limit socialization (see Frey and Fisher, 2008). Further, like the central argument of this article: that a massively popular, wealthy rapper can provide meaningful pedagogical guidance for critical educators, I have also argued that the mainstream and profit-driven companies like MySpace and Facebook can build important socializing spaces for critical dialogue and student support (Garcia, 2008). Through reimagining his relationship with an audience of millions, West demonstrates ways to challenge traditional power structures-a model that can be forged within today's classrooms.

A year before the Occupy movement would capture America's consciousness and months before the Arab Spring more fully rolled across northern Africa, Kanye West demonstrated the possibilities of social media as tools for knowledge building and sustained interest. Though critical educators should rightfully challenge West's capitalistic intentions, the pragmatic lessons of utility and philosophy with social media should not be disregarded. To date, West's album has sold more than one million physical copies (Recording Industry Association of America, 2013). His follow up tour a year later, co-headlined by collaborator Jay- $Z$, was the highest grossing Hip Hop tour of 2011, making more than $\$ 48$ million in ticket sales (Lewis, 2011). To consider West's popularity anything of an underground phenomenon would be ludicrous.

It is important to recognize that West's lyrical content can lead to further disregard for the relevance of mainstream Hip Hop within the classroom. And the public persona that West plays up does little to convince critical educators to consider the possibilities that West represents. When West grabbed the microphone from Taylor Swift to decry that Beyonce did not win a 2009 MTV Award, even President Obama called West a "jackass" (BBC 2009). To be clear, I do not apologize or account for West's actions. Instead, the focus on the rapper's ability to expand the world of Hip Hop and the possibilities for critical educators mean looking beyond these actions; West's resources for engagement and community building offer myriad tools to encourage challenging and critiquing his non-critical work.

\section{Toward a Beautiful Dark Twisted Pedagogy}

West's every step in releasing the album, from ludicrous twitter messages to on-air blowups to banned album artwork meant that there was not a day that I was unable to catch up with the latest in the Kanye-verse. In all of these updates Kanye evolved the Hip Hop mixtape to its proper participatory-culture configuration: it is an "alwayson" amalgam of music, personality, and hype.

The pervasive nature of Kanye's approach to marketing My Beautiful Dark Twisted Fantasy is something educators can lift. How can we deconstruct classroom pedagogy to move beyond traditional application of emergent technologies? Is it really the best we can do to simply duplicate textbooks and textbook practices when equipping students with iPads and mobile devices? This is essentially reducing the possibilities of screen and 
interfaces to a glowing page. Likewise, pedagogy must incorporate the persistent "always-on" nature of West's approach. His persistence and personality are what helped transfer knowledge, interest, and passion for his work. Critical educators, qualms about West aside, must evaluate how this approach may be adopted for classroom use. Teachers should ask themselves, how is my practice pervasive? How does the work that I do in my classroom transform students' lives throughout the day?

\section{A year before the Occupy movement would capture America's consciousness and months before the Arab Spring more fully rolled across northern Africa, Kanye West demonstrated the possibilities of social media as tools for knowledge building and sustained interest.}

I want to reiterate that what West accomplished was not some secret phenomenon. West made abundant profits from his efforts. At the same time West was mirroring widely adopted digital practices at a highly visible level: responding to tweets, sharing updates, hosting online Q\&As and producing video and music content for others are all attributes of what youth can and do easily engage in while online. In essence, West's efforts mimic what young people regularly do on their own. He mimics the literacy and learning practices that take place outside the classroom. For educators, this is also an important reminder: classroom practices should mirror the real world settings that students will venture to after leaving our classrooms. Students are already experts in media production and West reminds us to bring in these outside skills.

How can critical educators adjust their teaching practice in light of the work of Kanye West? Perhaps this may not seem the most astutely worded of educationrelated questions, but a necessary one nonetheless. West makes participating and communicating with fans fun, memorable, and engaging. Classrooms can leverage similar tools to get young people excited, in conversation, and networking globally around classroom content. To be clear, I am not advocating co-opting youth practices within a classroom. On the contrary, I am speaking about a largescale effort to update the classroom into the kinds of networked ecologies that are utilized for interaction everywhere except for in schools. As Castells (2009) writes, "A network-based social structure is a highly dynamic, open system, susceptible to innovating without threatening its balance" (pp. 501-502).

A Beautiful Dark Twisted Pedagogy is one that envelops students in opportunities to engage with extrinsic and intrinsic rewards. It allows youth to speak back to the content and see work in dialogue. An instantiation of this pedagogy, despite the capitalistic intentions of its namesake, begins with "a dramatic reorganization of power relationships" (Castells, 2009, pp. 502) and funnels classroom agency toward youth. It begins with youth interest and quickly amplifies key concepts that resonate within a classroom and well beyond. Like West, this shift toward meaningful engagement is one that requires educators to remain attuned to the interests and cultural landmarks of youth culture as entre into dialogues about socially conscious curriculum. The corners of commercialism-video games, music videos on YouTube, series on MTV-are going to function as signals for how young people's attention is being drawn both outside of schools and in classrooms. Instead of merely challenging the messages, images, and intentions of these multimodal texts, this is a pedagogy that can use these as starting places for youth-oriented production. Youth can remix and speak back to dominant texts not solely as classroom exercises but as public statements to be shared in the same social networks that they utilize daily.

In this sense My Beautiful Dark Twisted Fantasy illustrates ways transmedia storytelling (Jenkins, Ford and Green, 2013) and textual play can emerge fluidly with the many digital pathways enabled for youth. Transmedia, as described here, are media products that unfold across multiple platforms: a narrative may be told via movie productions, video game plotlines, comic books, and cartoons (as is the case with The Matrix series, for example). Instead of looking at a novel as a singular and definitive version of a text, the notion of transmedia allows youth literacies to demonstrate the text as a hub for building upon and collaboration. How can the canonical text taught in a classroom extend learning from the context of the Shakespearean era to contemporary social issues for youth. We can see burgeoning examples of this now: a quick search on Facebook and it is clear I can friend dozens of Holden Caulfields and Othellos and Katniss Everdeens: teachers and students alike are using today's tools to extend stories across various forms. These are not concepts presently being taught in teacher education programs and a Beautiful Dark Twisted Pedagogy calls for intentionality in this respect.

West's album ends with the song "Who Will Survive in America," built primarily around an excerpt from a 1970 poem by Gil Scott Heron, "Comment \#1." This finds West not only recontextualizing a critique of leftist organizing in the late sixties and seventies for the modern day but also continuing a dialogue between West's and Heron's work that extended across several albums; in 2005, West sampled a different Heron poem for his song "My Way Home"; Heron responded with a sample of West's "Flashing Lights" for his final album, I'm New Here in 2010. West builds upon, reinterprets, and engages in conversation with Heron's work. The narrative and melodic dialogue spreads across three albums and invites listeners to rethink the lyrics, music, and context for both works. It is a transformative work that challenges critical new literacies to build upon the notion of the "meme" as an educational possibility (Lankshear and Knobel, 2006).

With memes helping describe quickly spreading, "viral", media across networks, literature on memes often credits Dawkins (1976) with imbuing the term as a unit that spreads cultural content over time. As not merely a delivery system of information, memes effectively write upon the world and change it. In their 1987 text, Freire and Macedo describe literacy as a process of reading the 
world and then reading the word. It is an order often lost in discussions of Freire's development of critical literacies: cultural, "worldly" experience imbue the process of reading texts. West illustrates how advances in technology allow the world to be written upon and the need for educators to renegotiate their pedagogical stance.

\section{"No one man should have all that power": The Contradictions of Kanye}

In the lead single off of My Beautiful Dark Twisted Fantasy, "Power," West raps that "No one man should have all that power." It is a declaration that contributes to West's ongoing braggadocio. However, it is also a quote that is steeped in pedagogical meaning and historical precedent. A near word-for-word iteration of this quote was printed in 1957 in the Amsterdam News; a "stunned" police officer, noted about Malcolm X, "No one man should have that much power" (Marable, 2011, p. 128). It is likely that the quote was picked up by West in the 1992 Spike Lee directed biopic, $X$. This would not be the first time that Malcolm $X$ is invoked in West's lyrics. In "Good Morning" West claims he's "like the fly Malcolm $X$ buy any jeans necessary." Both invocations of the civil rights leader point back to the remixing and transmedia literacies that West demonstrates; they are necessary components of Beautiful Dark Twisted Pedagogy. However, I want to also return to the line from "Power" and its implications both for reflecting on West and for classroom practice.

As a self-critique, West's statement points to the problematic ways his performance of the Hip Hop genre upholds individuals and capitalism in boasts that separate fans through recognizable power structures. However, it is a model that West also challenges in content: the song "Power" was shared in multiple mixes before its profitable release on West's album with power and voice distributed (though not evenly) with his fans.

\section{References}

1. BBC News. (2009). Obama Calls Kanye West a Jackass. $B B C$ News. Retrieved January 24, 2013, from http://news.bbc.co.uk/2/hi/entertainment/8258330.stm.

2. Castells, M. (2009). The Rise of the Network Society, $2^{\text {nd }}$ ed. Oxford: Wiley-Blackwell.

3. Dawkins, R. (1976). The Selfish Gene. Oxford: Oxford University Press.

4. Freire, P. \& Macedo, D. (1987). Literacy: Reading the word and the world. Westport, CT: Bergin \& Garvey.

5. Frey, N., \& Fisher, D. (2008). Doing the Right Thing With Technology. English Journal, 97 (6): 38-42

6. Garcia, A. (2012a). Good reception: Utilizing mobile media and games to develop critical inner-city agents of social change. Unpublished doctoral dissertation, University of California, Los Angeles.

7. Garcia, A. (2012b). Inform, Perform, Transform: Modeling In-School Youth Participatory Action Research Through Gameplay. Knowledge Quest, 41 (1): 46-50.

8. Garcia, A. (2008). Rethinking MySpace: Using Social Networking Tools to Connect with Students. Rethinking Schools 22 (4): 27-29.

9. Jenkins, H., Clinton, K., Purushotma, R., Robison, A. J., \& Weigel, M. (2009). Confronting the challenges of participatory
From my own classroom experience, it is easy for critical educators to look at the realm of capitalism and disregard it wholesale; though I secretly indulged in West's music, I would deride it in discussions with my $11^{\text {th }}$ graders. And yet, while the content is a problematic perpetuation of marketing practices, the approaches themselves speak to the ways students are engaging, interacting, and approaching informal learning. Approaching the challenging domain of capitalism with a lens of pragmatic optimism, West illustrates the potential of participatory media as enacted by for-profit companies and illustrates ways these can be harnessed for wholesale social transformation.

Finally, in returning to West's lyric, "No one man should have all that power," it is important to notice that West distributes production, input, and narrative across various platforms with numerous points of input for others. It is a reflection of what radical educators' classrooms can look like. The decentralization of the teacher as singular leader within the classroom is neither new nor revolutionary. However, in looking at the ways teacherleaders, like West, can spark conversation, invite multimodal exploration, and direct connection with the community, the role of the teacher is not diminished as much as it is altered. Perhaps a problematic source for some, in terms of beginning a conversation of how critical pedagogy continues to shift in the $21^{\text {st }}$ Century, Kanye West's work illustrates practices our students are engaged in everyday. His work functions as a provocation for a redefinition of pedagogy that addresses the cultural shifts of participatory media. It is messy, problematic, and-in the liberatory possibilities it signals-beautiful. It is a pedagogy of hope for the digital age.

culture: Media education for the 21st century. MacArthur Foundation.

10. Jenkins, H., Ford, S., and Green, J. (2013). Spreadable media: Creating value and meaning in a networked culture. New York: NYU Press.

11. Lankshear C, Knobel M (2006). New literacies: Everyday Practices and classroom learning, 2nd ed. Maidenhead: Open University Press.

12. Lewis, R. (2011). U2, Taylor Swift have highest-grossing concert tours of 2011. Los Angeles Times. Retrieved January 24, 2013, from http://latimesblogs.latimes.com/music blog/2011/12/u2taylor-swift-have-highest-grossing-concert-tours-of2011.html.

13. Marable, M. (2011). Malcolm X : a life of reinvention. New York: Viking.

14. Recording Industry Association of America. (2013). My beautiful dark twisted fantasy. Retrieved January 29, 2013, from

http://www.riaa.com/goldandplatinumdata.php?artist=\%22My +Beautiful+Dark+Twisted+Fantasy\%22.

15. Reynolds, S. (1999). Generation ecstasy: Into the world of techno and rave culture. New York: Routledge.

16. Vilensky, M. (2010). Kanye West and Justin Bieber bond, plan possible collaboration over Twitter. New York Media LLC. Retrieved January 24, 2013, from

http://www.vulture.com/2010/08/kanye west and justin bie ber b.html. 
17. Westhoff, B. (2011). Dirty South: OutKast, Lil Wayne, Soulja Boy, and the Southern Rappers Who Reinvented HipHop. Chicago: Chicago Review Press.

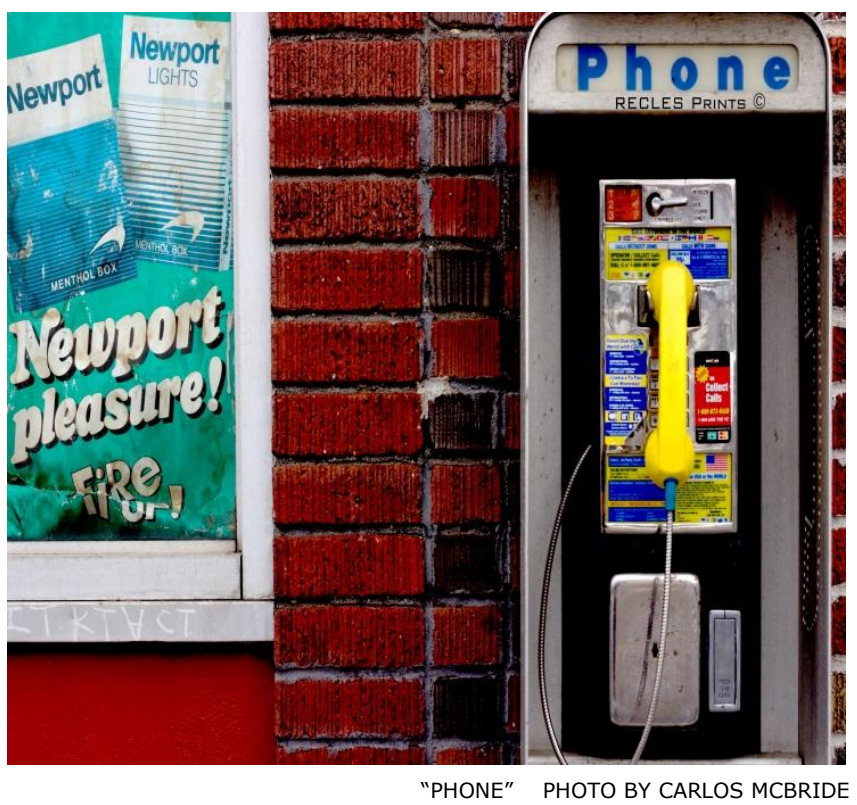

\section{RADICAL TEACHER}

